\title{
NMR and FTIR Characterization of Petroleum Residues: Structural Parameters and Correlations
}

\author{
Alexandre T. Castro* \\ Centro Tecnológico do Exército, Seção de Tecnologia de Materiais de Carbono, Av. das Américas, 28705, \\ 23020-470 Rio de Janeiro - RJ, Brazil
}

\begin{abstract}
Resíduos pesados de petróleo podem ser usados como matéria-prima na produção de diversos materiais de carbono, como piches, isotrópicos e anisotrópicos, e diferentes tipos de coque. A caracterização química destes resíduos, e de materiais de carbono em geral, é um desafio que deve ser abordado para que se possa otimizar adequadamente estes processos de produção. Neste trabalho, resíduos de petróleo de diferentes refinarias foram analisados por RMN, FTIR e análise elementar. Parâmetros de análise foram otimizados para a técnica de RMN e espectroscopia no infravermelho por refletância difusa, uma técnica geralmente aplicada a materiais sólidos, mas que gerou espectros de boa qualidade para estas amostras. Correlações foram encontradas entre os índices de aromaticidade por RMN e FTIR, um parâmetro largamente usado no estudo da formação da mesofase, bem como entre a razão $\mathrm{C} / \mathrm{H}$ e o índice de aromaticidade. Outros parâmetros estruturais de interesse também foram determinados.
\end{abstract}

Heavy petroleum residues can be used as raw materials in the production of various carbon products, notably isotropic and anisotropic pitches and different types of coke. The chemical characterization of these residues, and carbon materials in general, is a challenge that has to be addressed in order to allow the adequate optimization of production processes. In this study, petroleum residues of different refineries were studied by NMR, FTIR and elemental analysis. Optimum parameters were determined for NMR analysis and diffuse reflectance spectroscopy (DRIFTS), a technique that is usually applied to solid materials but was shown to yield good quality spectra for these samples. Correlations were found between NMR and FTIR results for the aromaticity index, a structural parameter widely used in the study of mesophase formation in pitches, as well as between $\mathrm{C} / \mathrm{H}$ ratios and the aromaticity index. Other structural parameters of interest were also obtained.

Keywords: decant oil, nuclear magnetic resonance, FTIR, diffuse reflectance

\section{Introduction}

Structural characterization of carbon materials precursors, such as heavy petroleum residues, is a challenge that must be addressed in order to adequately optimize production processes. The chemical complexity of these materials - where more than a thousand compounds are present, ${ }^{1}$ however, has meant that obtaining detailed information about its chemical composition is not practical and a number of average structural parameters have been employed instead. A number of these parameters has been generally calculated from nuclear magnetic resonance analysis, with some simpler ones obtained from infrared spectroscopy, even

*e-mail: tascheto@centroin.com.br though in many cases the calculations depend on assumptions that introduce considerable errors in the results. ${ }^{2}$ These parameters are frequently employed in the construction of average molecules, which serve as a way of visualizing the structural differences between various samples, even though these structures become less representative as the samples analyzed become more heterogeneous, so that there is some controversy regarding their usefulness. ${ }^{3}$

The simplest, and most employed, parameter is the aromaticity index, obtained either from FTIR or NMR, ${ }^{4,5}$ which is an indicative of the growth of polyaromatic systems, a fundamental step in the formation of cokes and pitches. Using NMR analysis, the aromaticity index is obtained as the ratio of aromatic carbon to total carbon or aromatic hydrogen to total hydrogen. In FTIR analysis, 
the ratio of the intensities (or areas) of peaks above 3000 $\mathrm{cm}^{-1}$ (aromatic C-H) and between $2700-3000 \mathrm{~cm}^{-1}$ (aliphatic C-H) is used.

Aromaticity indexes are ideally obtained from ${ }^{13} \mathrm{C}$ NMR spectra, which provide direct information about the carbon structures present, but this analysis is by far the most time consuming. ${ }^{1} \mathrm{H}$ NMR spectra can be obtained in a much shorter time, and a semi-empirical correlation between aromaticity indexes obtained from ${ }^{1} \mathrm{H}$ and ${ }^{13} \mathrm{C}$ spectra (which will be referred to as hydrogen and carbon aromaticity indexes, respectively) was obtained for a variety of coal and petroleum-derived liquids, ${ }^{6}$ but few heavy residues were analyzed in that study. FTIR is the simplest and cheapest method and its use in substitution of ${ }^{1} \mathrm{H}$ NMR spectra has been studied for coal-derived liquids. ${ }^{5}$

In this study, relationships between aromaticity indexes obtained from NMR spectra (both ${ }^{1} \mathrm{H}$ and ${ }^{13} \mathrm{C}$ ), FTIR spectra and $\mathrm{C} / \mathrm{H}$ ratios were studied for samples of decant oil, the residue obtained from catalytic cracking in petroleum refineries, a heavy petroleum fraction frequently used as raw material in the production of petroleum pitches for carbon fiber spinning and needle coke.

FTIR spectra were obtained using the diffuse reflectance technique (DRIFTS), widely used for the analysis of carbon materials because of their high scattering and low transmission, which tend to cause severe baseline distortion in standard transmission spectra. Even though it is a technique generally applied to solid materiais, this technique was found to be adequate to the analysis of liquids of high viscosity such as the samples analyzed in this study.

\section{Experimental}

Eight decant oil samples received from different refineries and one lighter fraction obtained by distillation of a sample of decant oil (labeled A-I) were analyzed by NMR, FTIR and elemental analysis. NMR analysis was performed on a Varian Unity $300 \mathrm{MHz}$ spectrometer with samples dissolved in deuterochloroform, at 40-50\% v/v, and TMS used as reference. Quantitative ${ }^{13} \mathrm{C}$ spectra were obtained using the inverse gated decoupling pulse sequence, with no relaxation agent and a 10 second pulse delay, which was determined to be sufficient for these samples. Integration regions used for ${ }^{13} \mathrm{C}$ spectra were $0-70 \mathrm{ppm}$ for aliphatic carbon, 100-170 ppm for aromatic carbon; for ${ }^{1} \mathrm{H}$ spectra, 0-4 ppm for aliphatic hydrogen, 6-9 ppm for aromatic hydrogen. Three spectra were obtained for each sample. DEPT analysis was performed to identify $\mathrm{CH}_{\mathrm{n}}$ groups.

Between six and twelve FTIR spectra were obtained for each sample on a Nicolet FTIR Protégé 460 equipment, fitted with a Pike Technologies diffuse reflectance accessory, at 160 scans and $2 \mathrm{~cm}^{-1}$ resolution. Concentration of the samples in $\mathrm{KBr}$ was varied up to $3 \%$ in order to determine the range in which a quantitative linear response was obtained. Final spectra were thus obtained at a concentration of $0.5 \%$ in $\mathrm{KBr}$. Elemental analysis was performed on a ThermoFinnigan Flash EA1112 in CHN configuration, calibrated with a lubricant oil standard.

\section{Results and Discussion}

FTIR and NMR spectra were qualitatively similar for all samples (Figure 1) and aromaticity indexes and elemental analysis data obtained are shown in Table 1.

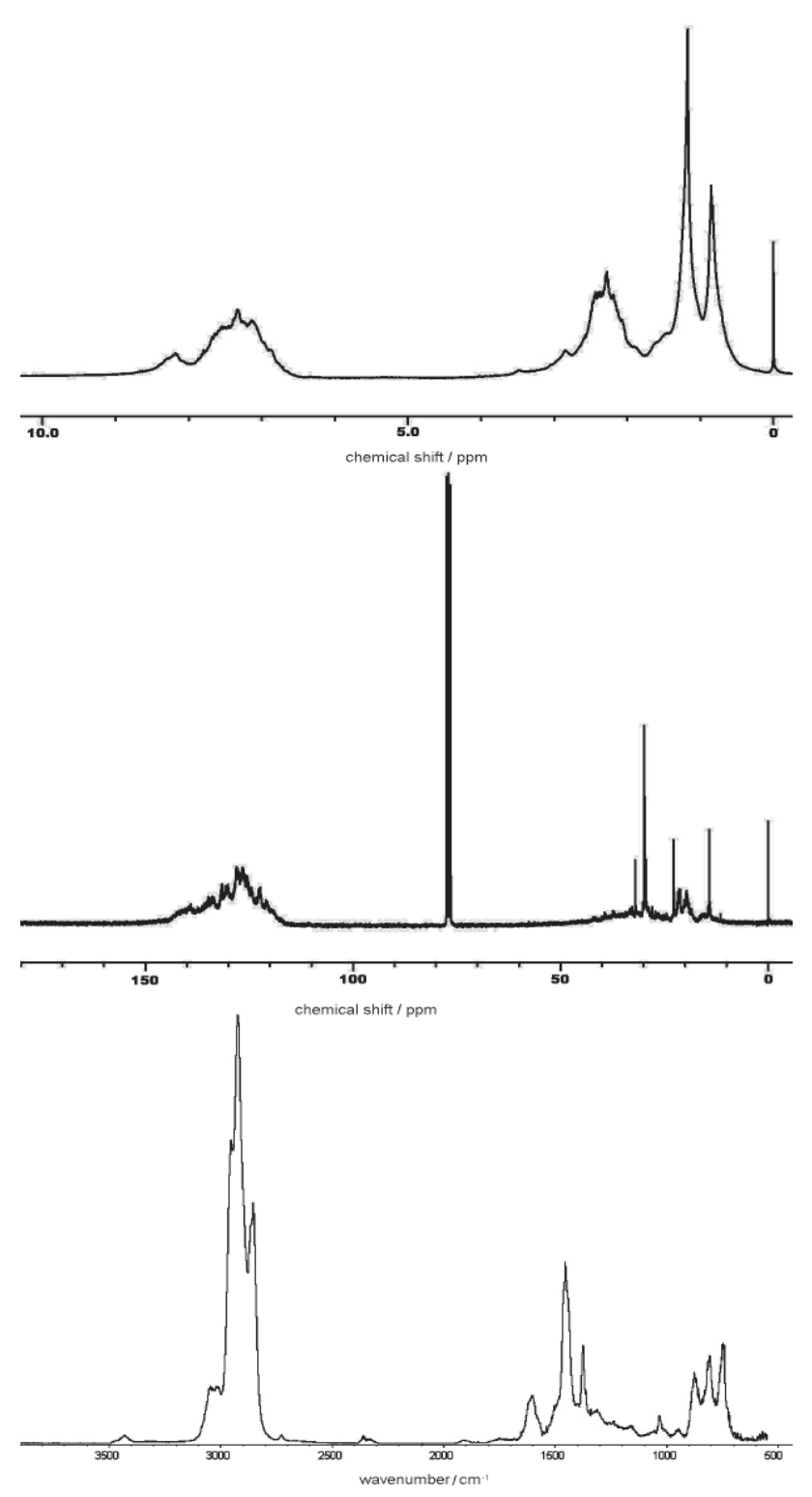

Figure 1. Typical NMR and DRIFTS spectra of decant oil. 
Table 1. Experimental data obtained for decant oil samples. Standard deviations in parenthesis

\begin{tabular}{|c|c|c|c|c|c|}
\hline \multirow[t]{2}{*}{ Sample } & \multicolumn{3}{|c|}{ Aromaticity } & \multirow[t]{2}{*}{$\% \mathrm{C}$} & \multirow[t]{2}{*}{$\% \mathrm{H}$} \\
\hline & ${ }^{13} \mathrm{C}$ NMR (\%) & ${ }^{1} \mathrm{H}$ NMR (\%) & FTIR (\%) & & \\
\hline A & $67.2(0.2)$ & $29.1(0.7)$ & $22.0(0.8)$ & $89.63(0.27)$ & $7.99(0.04)$ \\
\hline B & $73.8(1.3)$ & $37.3(0.3)$ & $33.9(0.7)$ & $90.92(0.51)$ & $7.51(0.17)$ \\
\hline $\mathrm{C}$ & $61.9(1.3)$ & $25.3(0.1)$ & $18.7(0.4)$ & $90.21(0.54)$ & $8.26(0.08)$ \\
\hline $\mathrm{D}$ & $64.5(1.3)$ & $27.2(0.7)$ & $21.8(0.5)$ & $89.46(0.45)$ & $8.10(0.05)$ \\
\hline $\mathrm{E}$ & $56.2(0.3)$ & $21.5(0.3)$ & $12.9(1.3)$ & $89.23(0.52)$ & $8.73(0.05)$ \\
\hline $\mathrm{F}$ & $63.7(0.4)$ & $27.7(0.4)$ & $20.6(1.7)$ & $90.36(0.24)$ & $8.55(0.05)$ \\
\hline G & 64.3 (1.6) & $27.5(0.2)$ & $18.9(1.1)$ & $89.69(0.41)$ & $8.22(0.02)$ \\
\hline $\mathrm{H}$ & $50.1(1.0)$ & $17.4(0.3)$ & $10.4(1.5)$ & $89.95(0.24)$ & $9.71(0.08)$ \\
\hline I & $53.1(0.3)$ & $20.6(0.4)$ & $14.58(2.1)$ & $87.81(0.16)$ & $8.96(0.07)$ \\
\hline
\end{tabular}

Table 2. Calculated structural parameters for decant oil samples

\begin{tabular}{lccccccccc}
\hline & $\mathrm{A}$ & $\mathrm{B}$ & $\mathrm{C}$ & $\mathrm{D}$ & $\mathrm{E}$ & $\mathrm{F}$ & $\mathrm{G}$ & $\mathrm{H}$ \\
\hline $\mathrm{C} / \mathrm{H}$ & 0.941 & 1.016 & 0.916 & 0.927 & 0.857 & 0.887 & 0.915 & 0.777 \\
$(\mathrm{C} / \mathrm{H})_{\text {arom }}$ & 2.173 & 2.010 & 2.241 & 2.198 & 2.240 & 2.040 & 2.139 & 2.237 & 2.119 \\
$(\mathrm{C} / \mathrm{H})_{\text {ali }}$ & 0.435 & 0.425 & 0.467 & 0.452 & 0.478 & 0.455 & 0.451 & 0.469 & 0.486 \\
$\mathrm{C}_{\text {arom }} / \mathrm{C}$ & 0.672 & 0.738 & 0.619 & 0.645 & 0.562 & 0.637 & 0.643 & 0.501 & 0.531 \\
$\mathrm{C}_{\text {arom-H }} / \mathrm{C}$ & 0.309 & 0.367 & 0.276 & 0.293 & 0.251 & 0.312 & 0.301 & 0.224 \\
$\mathrm{C}_{\text {arom--C }} / \mathrm{C}$ & 0.363 & 0.371 & 0.343 & 0.352 & 0.311 & 0.325 & 0.342 & 0.277 \\
$\mathrm{C}_{\text {ali }} / \mathrm{C}$ & 0.328 & 0.262 & 0.381 & 0.355 & 0.438 & 0.363 & 0.357 & 0.499 \\
$\mathrm{H}_{\text {arom }} / \mathrm{H}$ & 0.291 & 0.373 & 0.253 & 0.272 & 0.215 & 0.277 & 0.275 & 0.174 \\
$\mathrm{H}_{\text {ali }} / \mathrm{H}$ & 0.709 & 0.627 & 0.747 & 0.728 & 0.785 & 0.723 & 0.725 & 0.469 \\
$\mathrm{H}_{\alpha} / \mathrm{H}_{\text {arom }}$ & 1.127 & 0.941 & 1.170 & 1.081 & 1.098 & 1.061 & 1.080 & 0.206 \\
$\mathrm{H}_{\alpha} / \mathrm{C}_{\text {arom }}$ & 0.519 & 0.468 & 0.522 & 0.492 & 0.490 & 0.520 & 0.505 & 0.126 \\
\hline
\end{tabular}

$\mathrm{C} / \mathrm{H}$ ratios and other calculated structural parameters are shown in Table 2.

Cookson et al. ${ }^{6}$ obtained carbon and hydrogen aromaticity indexes for a number of coal- and petroleumderived liquids and introduced the hypothesis that the $\mathrm{C} / \mathrm{H}$ ratio for aromatic structures was proportional to the $\mathrm{C} / \mathrm{H}$ ratio for aliphatic structures present in the samples. This worked well for samples with low aromaticity indexes, but deviations were increasingly significant for more aromatic liquids. In fact, it is obvious from the results shown in Table 2 that this does not apply to decant oil samples analyzed in this study. Cookson's hypothesis led to a relationship between carbon $\left(\mathrm{Ar}_{\mathrm{C}}\right)$ and hydrogen $\left(\mathrm{Ar}_{\mathrm{H}}\right)$ aromaticity indexes given by $\mathrm{Ar}_{\mathrm{C}}=\left[\mathrm{k}\left(\left(\mathrm{Ar}_{\mathrm{H}}\right)^{-1}\right)-0.01\right)+$ $0.01]$. The results obtained in this study, however, indicate a simpler linear correlation between $\mathrm{Ar}_{\mathrm{C}}$ and $\mathrm{Ar}_{\mathrm{H}}$ for the samples of decant oil (Figure 2):

$\mathrm{Ar}_{\mathrm{C}}=29.14+1.25 \mathrm{Ar}_{\mathrm{H}} \quad \mathrm{R}=0.9834$

This linear correlation indicates a low degree of aromatic condensation in these samples, as aromatic bridgehead (or "internal") carbons are obviously not accounted for in ${ }^{1} \mathrm{H}$ NMR.

A good linear correlation was also found between FTIR and ${ }^{1} \mathrm{H}$ NMR aromaticity indexes. Various methods for

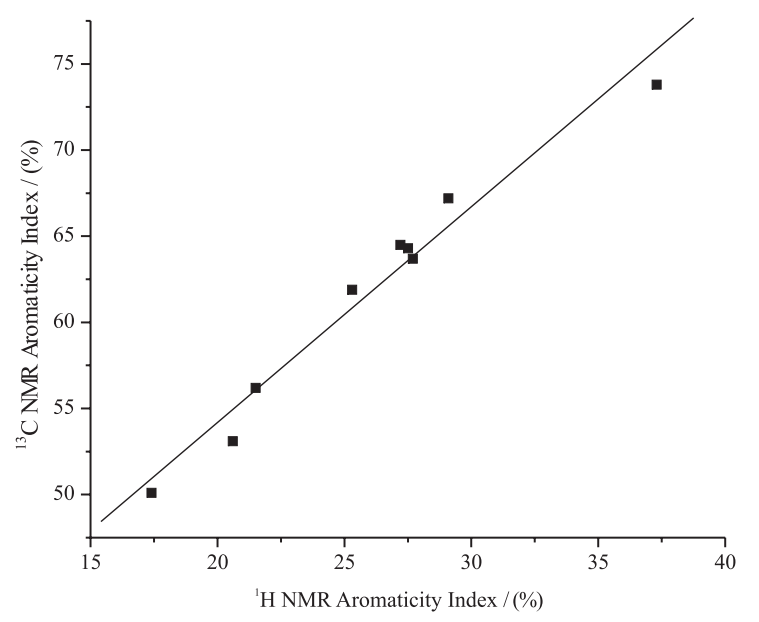

Figure 2. Relationship between aromaticity indexes obtained from ${ }^{1} \mathrm{H}$ and ${ }^{13} \mathrm{C}$ spectra.

the calculation of the aromaticity index from the FTIR spectra can be found in the literature, using area integration or peak intensities, as well as different baseline definitions. ${ }^{7}$ Figure 3 shows the correlation obtained between aromaticity indexes determined from ${ }^{1} \mathrm{H}$ NMR and FTIR spectra, using the ratio of peaks at $3050 \mathrm{~cm}^{-1}$ for aromatic C-H and $2855 \mathrm{~cm}^{-1}$ for aliphatic C-H, with a single baseline between 2750 and $3200 \mathrm{~cm}^{-1}$.

$$
\mathrm{Ar}_{\mathrm{H}}=9.89+0.83 \operatorname{Ar}_{\mathrm{FTIR}} \quad \mathrm{R}=0.9806
$$




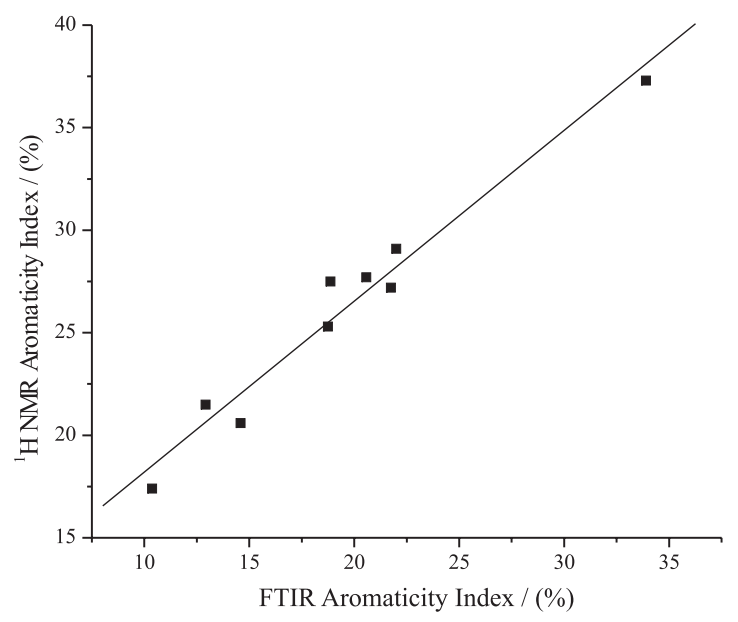

Figure 3. Relationship between aromaticity indexes obtained from FTIR and ${ }^{1} \mathrm{H}$ NMR.

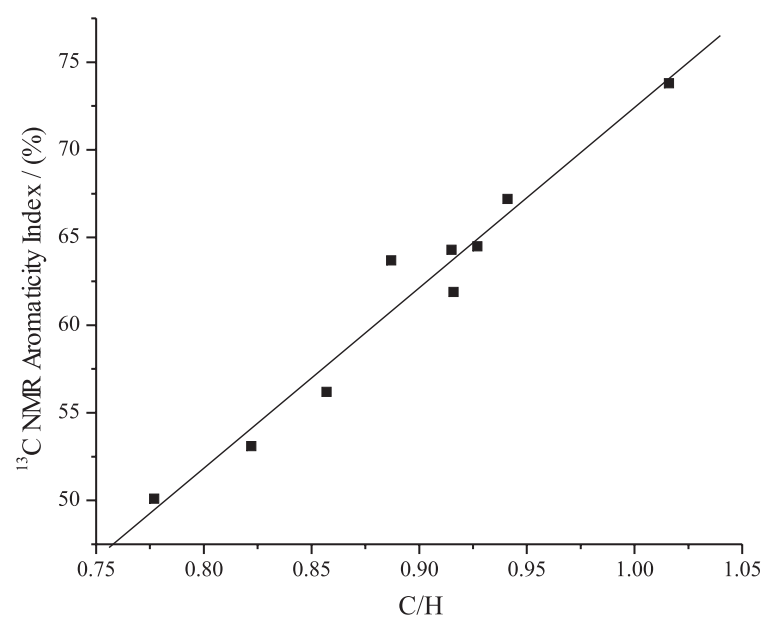

Figure 4. Relationship between $\mathrm{C} / \mathrm{H}$ ratio and ${ }^{13} \mathrm{C}$ aromaticity index.

The $\mathrm{C} / \mathrm{H}$ ratios also showed a clear linear correlation with the NMR aromaticity indexes (Figure 4):

$\mathrm{Ar}_{\mathrm{C}}=-30.49+102.91(\mathrm{C} / \mathrm{H}) \quad \mathrm{R}=0.9802$

Several structural parameters can be calculated from NMR spectra, but it was decided not to obtain parameters that involved unconfirmed assumptions about limits of integration areas, as the uncertainty associated with these assumptions are difficult to estimate. Even so, the simple parameters obtained from aromaticity indexes and $\mathrm{C} / \mathrm{H}$ ratios (Table 2) can be used as a quantitative indication of the chemical differences between samples.

Since DEPT analysis showed that the amount of branched aliphatic structures in these samples is not significant (Figure 5), the $(\mathrm{C} / \mathrm{H})$ ratio for aliphatic structures $-(\mathrm{C} / \mathrm{H})_{\text {ali }}$ - can be used directly as a measure of the average length of paraffinic chains, with values closer to 0.5 indicating longer chains. A clear linear correlation $(\mathrm{R}=0.9778)$ was found between $(\mathrm{C} / \mathrm{H})_{\text {ali }}$ and

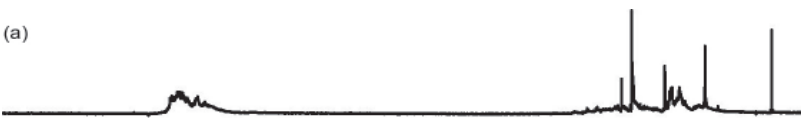

(b)

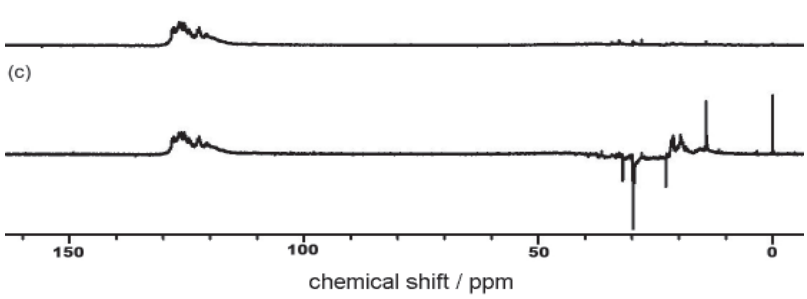

Figure 5. DEPT spectra of a decant oil. (a) all carbons; (b) $\mathrm{CH}$ carbons; (c) $\mathrm{CH}_{2}$ carbons down, $\mathrm{CH}_{3}$ carbons up.

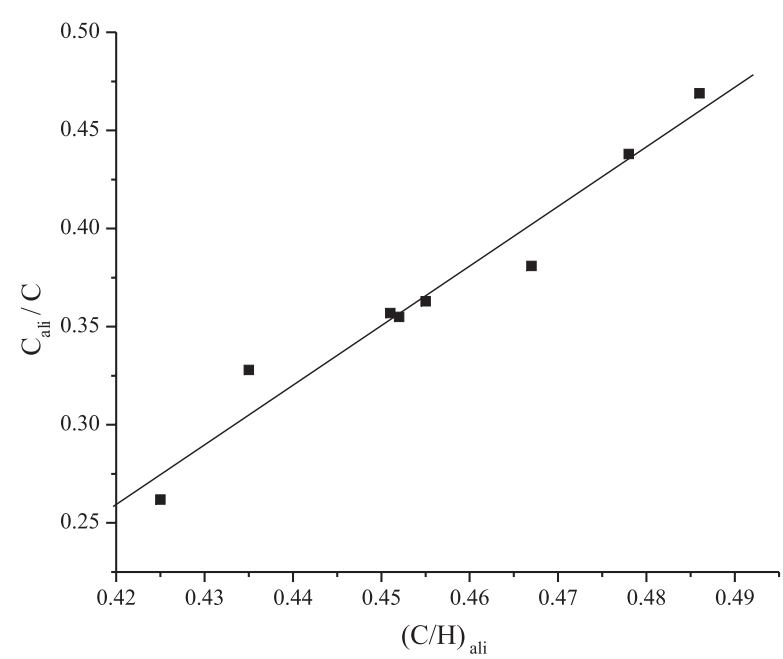

Figure 6. Relationship between ratio $\mathrm{C} / \mathrm{H}$ for aliphatic structures and fraction of aliphatic carbon for samples A-G, I.

$\mathrm{C}_{\mathrm{ali}} / \mathrm{C}_{\text {tot }}$ for this set of samples, when oil $\mathrm{H}$ is left out (Figure $6)$. This suggests that the mass content of aliphatic structures (in paraffinic and naphthenic molecules) is similar for this group of samples, with oil $\mathrm{H}$ having a considerably higher mass fraction of aliphatic structures. These samples are undergoing chromatographic analysis in order to confirm these conclusions.

The $\mathrm{C} / \mathrm{H}$ ratio for aromatic structures $-(\mathrm{C} / \mathrm{H})_{\text {arom }}-$ is affected simultaneously by aromatic condensation and substitution and it is difficult to identify each contribution precisely. However, an indication of aromatic substitution is given by the ratio $\mathrm{H}_{\alpha} / \mathrm{C}_{\text {arom }}$ (where hydrogens alpha to the aromatic ring are quantified from 1.8-4 ppm region of the NMR spectrum). Assuming a similar pattern of aromatic substitution for all samples - with similar $(\mathrm{H} /$ C) ${ }_{\alpha}$ ratios - this serves as an indication of the relative reactivity of these oils for pitch production, since polyaromatic growth in petroleum pitches occur mainly through free radical reactions, involving the cission of aromatic-alkyl bonds and formation of aryl bridges. ${ }^{8}$ 


\section{Conclusions}

The combination of NMR, FTIR and elemental analysis has been applied to the determination of structural parameters of decant oil samples. Useful correlations have been found between these techniques, suggesting that the faster and cheaper techniques of FTIR and elemental analysis can be used to obtain the carbon aromaticity index, usually derived from NMR data.

\section{Acknowledgments}

The author wishes to thank Petrobras, for supplying the samples analyzed in this study, and Prof. Jose Daniel Figueroa-Villar, for granting access to the NMR spectrometer at Instituto Militar de Engenharia, where NMR analysis was performed.

Financial support for this work was provided by Petrobras and FINEP (FNDCT-CTPETRO).

\section{References}

1. Greinke, R.A. In Chemistry and Physics of Carbon; Thrower, P.A., ed.; Marcel Dekker: New York, 1994, vol. 24, ch.1.

2. Gillet, S.; Rubini, P.; Delpuech, J.-J.; Escalier, J.-C.; Valentin, P.; Fuel 1981, 60, 226; Rongbao, L.; Zengmin, S.; Bailing, L.; Fuel 1988, 67, 565; Rodriguez, J.; Tierney, J. W.; Wender, I.;
Fuel 1994, 73, 1870; Doan, B.-T.; Gillet, B.; Blondel, B.; Beloeil, J.-C.; Fuel 1995, 74, 1806; Christopher, J.; Sarpal, A. S.; Kapur, G. S.; Krishna, A.; Tyagi, B. R.; Jain, M. C.; Jain, S. K.; Bhatnagar, A. K. Fuel 1996, 75, 999; Michon, L.; Martin, D.; Planche, J.-P.; Hanquet, B.; Fuel 1997, 76, 9; Calemma, V.; Pausa, R.; D’Antona, P.; Montanari, L.; Energy Fuels 1998, 12, 422; Kapur, G. S.; Berger, S.; Fuel 2002, 81, 883; Kapur, G. S.; Berger, S.; Energy Fuels 2005, 19, 508.

3. Altgelt, K. H.; Boduszynski, M. M.; Compostion and Analysis of Heavy Petroleum Fractions, Marcel Dekker: New York, 1994.

4. Brown, J. K.; Ladner, W. R.; Fuel 1960, 39, 87; Retcofsky, H. L.; Schweighardt, F. K.; Hough, M.; Anal. Chem. 1977, 49, 585; Yoshida, T.; Maekawa, Y.; Uchino, H.; Yokoyama, S.; Anal. Chem. 1980, 52, 817.

5. Wang, C.; Fuel 1987, 66, 840; Sobkowiak, M.; Painter, P.; Fuel 1992, 71, 1105; Cerny, J.; Fuel 1996, 75, 1301.

6. Cookson, D. J.; Lloyd, C. P.; Smith, B. E.; Fuel 1986, 65, 1247.

7. Kaihara, M.; Mametsuka, H.; Gunji, N.; Gohshi, Y.; Fuel 1991, 70, 931; Guillen, M. D.; Iglesias, M. J.; Dominguez, A.; Blanco, C. G.; Energy Fuels 1992, 6, 518; Martínez-Escandell, M.; Torregrosa, P.; Marsh, H.; Rodríguez-Reinoso, F.; SantamariaRamírez, R.; Gómez-De-Salazar, C.; Romero-Palazón, E.; Carbon 1999, 37, 1567.

8. Greinke, R. A.; Lewis, I. C.; Carbon 1984, 22, 305; Greinke, R. A.; Carbon 1992, 30, 407.

Received: February 1, 2006 Published on the web: July 13, 2006 